\title{
STRATEGI TATA KELOLA PERENCANAAN DAN PEMANFAATAN TIK GUNA MENDUKUNG PENINGKATAN KUALITAS SPBE DI BSN
}

\author{
Good Governance Planning and Utilization Strategy for Using ICT to Support \\ Quality Improvement SPBE in BSN
}

\author{
Nila Yantrisiana Puspitasari, Andrew AMS Pane \\ Badan Standardisasi Nasional, Gedung I BPPT, JI. MH Thamrin No. 8, Jakarta Pusat \\ e-mail: nila.yantrisiana@bsn.go.id
}

\begin{abstract}
Abstrak
Dalam era 4.0 sekarang ini, maka pemanfaatan teknologi informasi menjadi keharusan bagi Badan Standardisasi Nasional (BSN) untuk mendukung efisiensi, efektivitas dan peningkatan layanan kepada masyarakat. Saat ini BSN telah memanfaatkan teknologi hampir di seluruh unit kerja, akan tetapi pemanfaatan teknologi informasi tersebut belum didukung dengan tersedianya tata kelola dan perencanaan yang bagus, baik dalam hal sumber daya manusia pendukung (SDM), perencanaan keuangan maupun perencanaan teknis. Banyak terjadi tumpang tindih pemanfaatan teknologi informasi antar unit kerja di BSN akibat tidak tersesinya tata kelola dan perencanaan pemanfaatan TIK. Hal ini juga mempengaruhi hasil evaluasi penerapan Sistem Pemerintahan Berbasis Elektronik tahun 2018 dengan nilai indeks 2.27 dengan kategori Cukup. Oleh karena itu, perlu dilakukan evaluasi terhadap pemanfaatan TIK di lingkungan BSN dengan melakukan survey pemanfaatan teknologi informasi dan komunikasi pada tahun 2019 terhadap seluruh unit kerja di lingkungan BSN sebagai langkah awal dalam melakukan perbaikan baik di sisi kebijakan, tata kelola maupun layanan berbasis elektronik. Hasil pengolahan data survei tersebut juga dijadikan dasar pertimbangan evaluasi terhadap strategi dan tata kelola perancanaan pemanfaatan TIK di BSN yang disesuaikan berdasarkan rencana induk SPBE BSN. Ruang lingkup penelitian ini hanya terbatas pada Kebijakan Internal SPBE dimana hasil akhirnya berupa suatu kebijakan yang telah ditetapkan oleh Kepala BSN berbentuk Keputusan Kepala Badan Standardisasi Nasional Nomor 316A/KEP/BSN/7/2019 tentang Pernyataan Kebijakan Internal Layanan Sistem Pemerintahan Berbasis Elektronik.
\end{abstract}

Kata kunci: tata kelola, sistem pemerintahan berbasis elektronik, teknologi informasi dan komunikasi.

\begin{abstract}
In the current 4.0 era, the use of information technology is a must for the National Standardization Agency (BSN) to support efficiency, effectiveness and improvement of services to the public. Currently BSN has utilized technology in almost all work units, but the utilization of information technology has not been supported by the availability of good governance and planning, both in terms of supporting human resources (HR), financial planning and technical planning. Many overlaps in the use of information technology between work units in BSN due to the lack of good governance and planning for the use of ICT. This also affects the results of evaluating the application of the Sistem Pemerintahan Berbasis Elektronik (SPBE) in 2018 with an index value of 2.27 with the "Cukup" category. Therefore, it is necessary to evaluate the use of ICT in the BSN environment by conducting a survey of the use of information and communication technology in 2019 of all work units in the BSN environment as a first step in making improvements both in terms of policy, good governance and electronic-based services. The results of the survey data processing are also used as a basis for consideration of evaluating the strategy and management of ICT utilization planning in BSN adjusted according to the BSN SPBE master plan. The scope of this research is only limited to the SPBE Internal Policy where the end result is a policy that has been determined by the Head of BSN in the form of a Decree of the Head of the National Standardization Agency Number 316A / KEP / BSN / 7/2019 concerning Statement of Internal Policy in Sistem Pemerintahan Berbasis Elektronik Services.
\end{abstract}

Keywords: good governance, Sistem Pemerintahan Berbasis Elektronik (SPBE), information and communication technology

\section{PENDAHULUAN}

\subsection{Latar Belakang}

Saat ini, Indonesia sudah memasuki era industri 4.0 dimana dunia industri telah menggabungkan teknologi otomatisasi dengan teknologi cyber yang mencakup sistem cyberfisik, internet of things (loT), komputasi awan, dan komputasi kognitif. Tren ini tidak saja memperikan dampak perubahan yang eksponensial di bidang industri manufaktur, namun juga di sisi pemerintahan yang memiliki dampak luas terhadap regulasi perekonomian di Indonesia. Dampak nyata industri 4.0 bagi pemerintahan yaitu merebaknya pemanfaatan teknologi informasi baik di pemerintahan pusat maupun daerah dimana segala layanan pemerintahan berbasis elektronik. Kementerian Perindustrian telah meluncurkan program Making Indonesia 4.0 yang merupakan peta 
jalan (roadmap) terintegrasi dan kampanye untuk mengimplementasikan strategi menghadapi era revolusi industri ke- 4 (Industry 4.0). Roadmap tersebut telah diluncurkan pada tangal 4 April 2018 sebagai implementasi nyata pemerintah ikut andil dalam tren revolusi industri ini. Selain itu, pada tanggal 2 Oktober 2018 juga ditetapkan Peraturan Presiden No. 95 Tahun 2018 tentang Sistem Pemerintahan Berbasis Elektronik (SPBE) dimana setiap kementerian dan lembaga instansi pusat maupun pemerintah daerah harus menerapkan sistem pemerintahan berbasis elektronik (SPBE) dengan unsur-unsur SPBE yang terdiri dari : Rencana Induk SPBE Nasional, Arsitektur SPBE, Peta Rencana SPBE, rencana dan anggaran SPBE, Proses Bisnis, data dan informasi, Infrastruktur SPBE, Aplikasi SPBE, Keamanan SPBE, dan Layanan SPBE. Penerapan SPBE ini juga dilakukan evaluasi secara berkala dimana Badan Standadisasi Nasional sudah berpartisipasi pada tahun 2018 dengan mendapatkan hasil Indeks SPBE dengan nilai 2,27 dengan kategori Cukup yang ditunjukkan pada Gambar 1 sedangkan pemanfaatan teknologi informasi dan komunikasi (TIK) di BSN juga semakin meningkat seiring waktu dengan melakukan digitalisasi terhadap bagian-bagian proses bisnis. Kedua hal ini menjadi tidak selaras dan bertentangan yang akan menghambat kinerja birokrasi dan pelayanan publik di lingkungan BSN dan tentunya peran serta BSN dinilai masih kurang terhadap visi SPBE yaitu terwujudnya sistem pemerintahan berbasis elektronik yang terpadu dan menyeluruh untuk mencapai birokrasi dan pelayanan publik yang berkinerja tinggi.

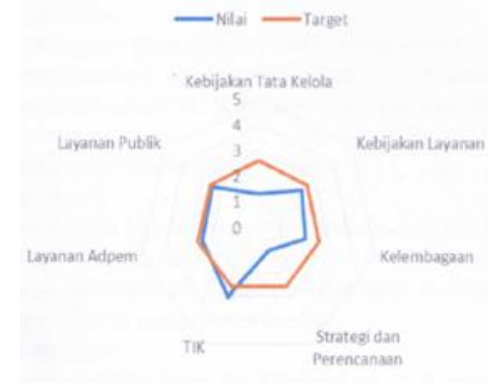

Gambar 1. Grafik Nilai Indeks SPBE BSN

Tabel 1. Kategori Indeks SPBE

\begin{tabular}{ccc}
\hline No & Nilai Indeks & Kategori \\
\hline 1 & $4.2-5$ & Memuaskan \\
2 & $3.5-<4.2$ & Sangat baik \\
3 & $2.6-<3.5$ & Baik \\
4 & $1.8-<2.6$ & Cukup \\
5 & $<1.8$ & Kurang \\
\hline
\end{tabular}

Selain itu, pemanfaatan teknologi informasi di BSN saat ini dilaksanakan tanpa perencanaan yang matang dan terintegrasi antar unit kerja. Masing-masing unit kerja membangun aplikasi untuk memenuhi kebutuhan masing-masing. Akibat dari hal tersebut ialah timbulnya masalahmasalah sebagai berikut:

a. Redudansi data dan informasi;

b. Laporan yang tidak valid;

c. Kesulitan untuk melakukan perawatan dan pengembangan aplikasi yang ada;

d. Kesulitan monitoring keamanan sistem.

Pada tahun 2019 ini, BSN memiliki target penerapan SPBE mendapatkan nilai indeks 3 dengan kategori Baik dimana hal ini menjadi dorongan utama terhadap instansi BSN untuk melakukan perbaikan berkesinambungan terhadap setiap kebijakan, tata kelola maupun layanan berbasis teknologi informasi dan komunikasi di lingkungan BSN.

\subsection{Tujuan}

Sesuai dengan latar belakang di atas, maka tujuan penelitian ini ialah "Menyediakan rancangan tata kelola pemanfaatan teknologi informasi dan komunikasi untuk mendukung peningkatan kualitas SPBE di BSN".

\subsection{Ruang Lingkup}

Penelitian ini hanya menitikberatkan pada lingkup penerapan SPBE di Badan Standardisasi Nasional dengan batasan di domain 1 yaitu Kebijakan Internal SPBE yang memiliki 2 aspek penilaian antara lain Kebijakan Internal Tata kelola SPBE dan Kebijakan Internal Layanan SPBE.

\section{TINJAUAN PUSTAKA}

\subsection{Tata Kelola Teknologi Informasi dan Komunikasi}

Penyelenggaraan pemerintahan dalam rangka pelayanan publik memerlukan Good Governance. Implementasi Good Governance akan menjamin transparansi, efisiensi, dan efektivitas penyelenggaraan pemerintahan. Salah satu langkah dalam mendukung inplementasi good governance adalah dengan memperhatikan tata kelola TIK pada instansi pemerintah.

Menurut ISACA (2010) : " IT Governance is responsibility of the board of Directors dan Executive Management. It is an integral part of enterprise governance and consist of the leadership and organizational structures and process that ensure the organization's IT sustains and extends the organization 's strategy and objectives." 
NC Saxena (2012) menegaskan bahwa " $E$ governance is less threatening to those in authority in contrast to some of the complex administrative reforms that have remained dormant in official reports".

Tata kelola TI memberikan panduan kepada penanggung jawab tata kelola dalam mengevaluasi, mengarahkan dan memantau penggunaan $\mathrm{TI}$ dalam organisassi. Penerapan tata kelola TI dapat mendorong organisasi dalam pemanfaatan Tl yang efektif dan efisien.

Manfaat tata kelola di institusi pemerintahan dapat dilihat dalam 3 perspektif yaitu nasional, institusional dan publik. Berdasarkan Peraturan Menkominfo nomor 41 tahun 2007 tentang panduan umum tata kelola teknologi informasi dan komunikasi nasional, diketahui bahwa model tata kelola TIK Nasional sebagai berikut :

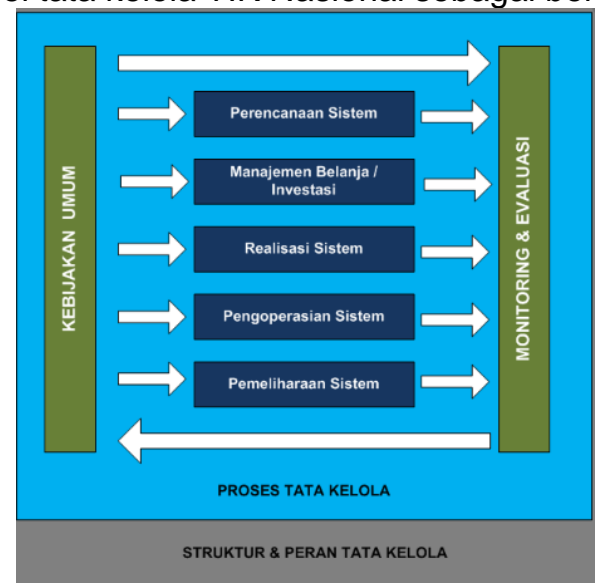

Gambar 2. Model tata Kelola TIK Nasional

1. Struktur dan peran tata kelola yaitu entitas apa saja yang berperan dalam pengelolaan proses-proses TIK dan bagaimana pemetaan perannya dalam pengelolaan proses-proses TIK tersebut. Struktur dan peran tata kelola ini mendasari seluruh proses tata kelola TIK.

2. Proses tata kelola

yaitu proses-proses yang ditujukan untuk memastikan bahwa tujuan-tuuan utama tata kelola dapat tercapai, terkait dengan pencapaian tujuan organisasi, pengelolaan sumber daya, dan manajemen risiko.

Pada dasarnya, sistem organisasi yang menyangkut didalamnya perancangan struktur organisasi dan penilaian efektivitas kinerjanya, akan sangat bergantung dari sejumlah faktor spesifik terkait dengan situasi dan kondisi organisasi (RE Indrajit, 2016 :8).

\subsubsection{Lingkup Proses Tata Kelola}

1. Perencanaan Sistem

Proses ini menangani identifikasi kebutuhan organisasi dan formulasi inisiatif-inisiatif TIK apa saja yang dapat memenuhi kebutuhan organisasi tersebut.

2. Manajemen Belanja/Investasi

Proses ini menangani pengelolaan investasi/belanja TIK

3. Realisasi Sistem

Proses ini menangani pemilihan, penetapan, pengembangan/akuisisi sistem TIK, serta manajemen proyek TIK.

4. Pengoperasian Sistem

Proses ini menangani operasi TIK yang memberikan jaminan tingkat layanan dan keamanan sistem TIK yang dioperasikan.

5. Pemeliharaan Sistem

Proses ini menangani pemeliharaan aset-aset TIK untuk mendukung pengoperasian sistem yang optimal.

\subsubsection{Mekanisme Proses Tata Kelola}

1. Kebijakan Umum

Kebijakan umum ditetapkan untuk memberikan tujuan dan batasanbatasan atas proses TIK bagaimana sebuah proses TIK dilakukan untuk memenuhi kebijakan yang ditetapkan.

2. Monitoring \& Evaluasi

Monitoring \& evaluasi ditetapkan untuk memastikan adanya umpan balik atas pengelolaan TIK, yaitu berupa ketercapaian kinerja yang diharapkan. Untuk mendapatkan deskripsi kinerja setiap proses TIK digunakan indikator keberhasilan. Indikator keberhasilan inilah yang akan dapat digunakan oleh manajemen atau auditor, untuk mengetahui apakah proses TIK telah dilakukan dengan baik.

Berdasarkan SNI ISO/IEC 38500:2016, model untuk tata kelola TI (siklus EvaluasiArahkan-Pantau) dapat dilihat pada gambar sebagai berikut : 


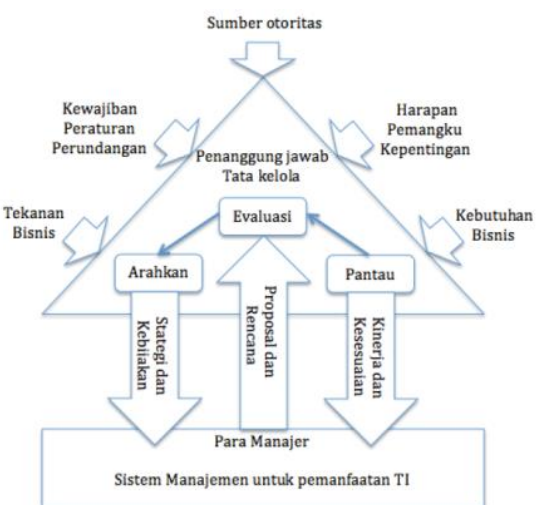

Gambar 3. Model untuk Tata Kelola TI (siklus Evaluasi-Arahkan-Pantau)

Pemanfaatan tata kelola TI yang baik dapat membantu penanggung jawab tata kelola untuk memastikan bahwa penggunaan TI berkontribusi positif terhadap kinerja instansi / organisasi. Kontribusi positif pemanfaatan tata kelola TI yang baik terhadap instansi/organisasi dapat dirasakan melalui inovasi dalam layanan, pasar dan bisnis, penyelarasan TI dengan kebutuhan bisnis, pelaksanaan dan pengoperasian asset TI yang tepat, kejelasan tanggung jawab dan akuntabilitas kedua sisi pasokan dan permintaan untuk TI dalam mencapai tujuan organisasi. Keberlangsungan dan keberlanjutan bisnis, alokasi daya yang efisien dan efektif, praktik yang baik dalam hubungan dengan para pemangku kepentingan dan realisasi aktual dari manfaat yang diharapkan dari setiap investasi TI.

\subsection{Sistem Pemerintahan Berbasis Elektronik}

Pemerintah dalam hal mewujudkan tata kelola pemerintahan yang bersih, efektif, transparan, dan akuntabel serta pelayanan publik yang berkualitas dan terpercaya memerlukan sistem pemerintahan berbasis elektronik.

Sistem Pemerintahan Berbasis Elektronik (SPBE) berdasarkan Perpres Nomor 95 Tahun 2018 adalah penyelenggaraan pemerintahan yang memanfaatkan teknologi informasi dan komunikasi untuk memberikan layanan kepada Pengguna SPBE.

SPBE mengandung rencana induk yang memuat visi, misi, arah kebijakan, strategi dan peta rencana strategis pembangaunan SPBE secara nasional. Dalam pelaksanaan SPBE diperlukan prinsip-prinsip seperti efektivitas, keterpaduan, kesinambungan, efisiensi, akuntabilitas, interoperabilitas dan keamanan. Maksudnya efektifitas adalah optimalisasi pemanfaatan sumber daya yang mendukung SPBE yang berhasil guna sesuai dengan kebutuhan. Keterpaduan merupakan pengintegrasian sumber daya yang mendukung SPBE. Kesinambungan merupakan keberlanjutan SPBE secara terencana, bertahap, dan terus menerus sesuai dengan perkembangannya. Efisiensi merupakan optimalisasi pemanfaatan sumber daya yang mendukung SPBE yang tepat guna. Akuntabilitas merupakan koordinasi dan kolaborasi antar Proses Bisnis dan antar sistem elektronik, dalam rangka pertukaran data, informasi, atau Layanan SPBE. Keamanan merupakan kerahasiaan, keutuhan, ketersediaan, keaslian, dan kenirsangkalan (nonrepudiation) sumber daya yang mendukung SPBE. Sesuai Perpres nomor 95 tahun 2018 tentang SPBE, maka unsur-unsur SPBE itu meliputi Rencana Induk SPBE Nasional, Arsitektur SPBE, peta Rencana SPBE, rencana dan anggaran SPBE, Proses Bisnis, data dan informasi, Infrastruktur SPBE, Aplikasi SPBE, Keamanan SPBE, Layanan SPBE.

Pemerintah melalui Kementrian PAN-RB melakukan kegiatan evaluasi SPBE di seluruh instansi pusat dan daerah. Tujuan dari evaluasi SPBE ini adalah agar mengetahui capaian pelaksanaan SPBE yang telah diterapkan di masing-masing instansi pusat maupun daerah, memberikan saran dan perbaikan terhadap pelaksanaan SPBE dan mengetahui peningkatan kualitas pelaksanaan SPBE, sehingga dengan demikian diharapkan dapat menghasilkan SPBE yang berkualitas, terintegrasi dan bermanfaat bagi instansi pemerintah, masyarakat, pelaku usaha, aparatur sipil negara. Tabel 1 di bawah ini merupakan domain, aspek dan indikator penilaian dalam evaluasi SPBE.

Tabel 2. Domain dan Aspek Perubahan dalam Evaluasi SPBE

\begin{tabular}{ll}
\hline Domain & \multicolumn{1}{c}{ Area Perubahan } \\
\hline Domain 1 & Kebijakan Internal SPBE \\
Aspek 1 & Kebijakan Internal Tata Kelola SPBE
\end{tabular}

Aspek 2 Kebijakan Internal Layanan SPBE

Domain 2 Tata Kelola SPBE

Aspek 3 Kelembagaan

Aspek 4 Strategi dan Perencanaan

Aspek 5 Teknologi Informasi dan Komunikasi

Domain 3 Layanan SPBE

Aspek 6 Layanan Administrasi Pemerintahan Berbasis Elektronik

Aspek 7 Layanan Publik Berbasis Elektronik 
Penerapan SPBE dinilai dengan metode tingkat kematangan SPBE yang merupakan kerangka kerja untuk mengukur derajat kematangan penerapan SPBE yang ditinjau dari kapabilitas proses dan kapabilitas fungsi teknis SPBE. Tingkat kematangan untuk kapabilitas proses dan kapabilitas fungsi teknis diukur dari skala 1-5. Untuk kapabilitas proses skala 1-5 yaitu skala 1 rintisan, skala 2 tekelola, skala 3 terstandardisasi, skala 4 terintegrasi dan terukur serta skala 5 optimum. Sedangkan untuk kapabilitas fungsi teknis skala 1-5 yaitu skala 1 informasi, skala 2 interaksi, skala 3 transaksi, skala 4 kolaborasi dan skala 5 optimalisasi. Mengukur tingkat kematangan (skala 1-5) pada indikator penilaian di domain kebijakan, tata kelola dan layanan SPBE.

\section{METODE PENELITIAN}

Metode penelitian yang digunakan dalam penelitian ini ialah menggunakan pengisian kuesioner dan kajian literatur.

\subsection{Kuesioner}

Salah satu instrumen yang dilakukan dalam penyusunan jurnal ini adalah kuesioner. Kuesiner ini berisikan serangkaian pertanyaan terkait dan menyebarkan kuesioner ke masingmasing pusat/biro dan Deputi. Masing-masing pusat/biro dan Deputi akan mengisi kuesioner dan dari hasil kuesioner tersebut dilakukan analisis. Pada hakikatnya, analisis data adalah sebuah kegiatan untuk mengatur, mengurutkan, mengelompokkan, memberi kode/tanda, dan mengategorikannya sehingga diperoleh suatu temuan berdasarkan fokus atau masalah yang ingin dijawab. Melalui serangkaian aktivitas tersebut, data kualitatif yang biasanya berserakan dan bertumpuktumpuk bisa disederhanakan untuk akhirnya bisa dipahami dengan mudah (Imam Gunawan, 2013:209).

\subsection{Kajian Literatur}

Kajian literatur dilakukan untuk mendukung dalam penulisan jurnal ini. Kajian literatur dilakukan dengan mengkaji dan mempelajari dokumen/berkas maupun mengumpulkan data baik berupa buku, peraturan perundangundangan, referensi, artikel, majalah, jurnal dan hasil penelitian yang ada. Tujuannya adalah untuk mendapatkan landasan teori, teknik, metode dan temuan-temuan lainnya mengenai apa yang akan di buat dalam artikel ini.

\subsection{Sumber Data}

Sumber data dalam penulisan jurnal ini merupakan sumber data primer. Data primer merupakan data yang diperoleh langsung dari objek penelitian. Sumber data diperleh dari hasil kuesioner yang diambil dari beberapa responden dari masing-masing pusat/biro di lingkungan BSN yang kemudian data tersebut akan diolah dan dianalisis sesuai kebutuhan dalam penulisan jurnal ini.

\subsection{Jenis Data}

Jenis data dalam penulisan jurnal ini adalah jenis data kualitatif. Data kualitatif merupakan data yang sifatnya abstrak karena berbentuk kata-kata yang bermakna. Data kualitatif diperoleh dengan metode pengumpulan data melalui kuesioner yang nantinya hasil kuesioner tersebut akan dianalisis untuk memperoleh hasil yang baik

\section{HASIL DAN PEMBAHASAN}

Berdasarkan pengolahan data pada hasil kuesioner kebutuhan teknologi informasi yang telah dilakukan terhadap 5 Unit Kerja Eselon I dan 19 Unit Kerja Eselon II dengan hasil survey yang diterima berasal dari 19 Unit Kerja di Eselon II di lingkungan Badan Standardisasi Nasional, pemanfaatan teknologi informasi semakin meningkat per tahunnya dimana terlihat Pusat/Biro yang paling banyak memanfaatkan teknologi informasi yaitu Biro SDMOH (Sumber Daya Manusia, Organisasi dan hukum) dan Pusat HKLI (HUMAS, Kerjasama dan Layanan Informasi) dimana kedua pusat/biro ini menitikberatkan pemanfaatan teknologi informasi untuk kepentingan internal BSN dan pelayanan informasi ke masyarakat terkait standardisasi dan penilaian kesesuaian yang ditunjukkan pada Gambar 3 dibawah ini. Hasil sampel yang diterima memenuhi kuota karena seluruh responden mengembalikan hasil survey beserta hasilnya. Hal ini menunjukkan bahwa Badan Standardisasi Nasional dinilai memang perlu menerapkan Sistem Pemerintahan Berbasis Elektronik (SPBE) dengan menyusun kebijakan terkait internal layanan SPBE selain karena diwajibkannya penerapan SPBE berdasarkan Peraturan Presiden No. 95 Tahun 2018. $\mathrm{Di}$ tahap awal, manajemen BSN menyusun Kebijakan Internal Tim Pengarah SPBE yang mengatur tugas dan tanggung jawab pihka-pihak terkait bidang TIK di lingkungan BSN dengan mengeluarkan Surat Keputusan Kepala BSN tentang Tim Pengarah SPBE BSN. 


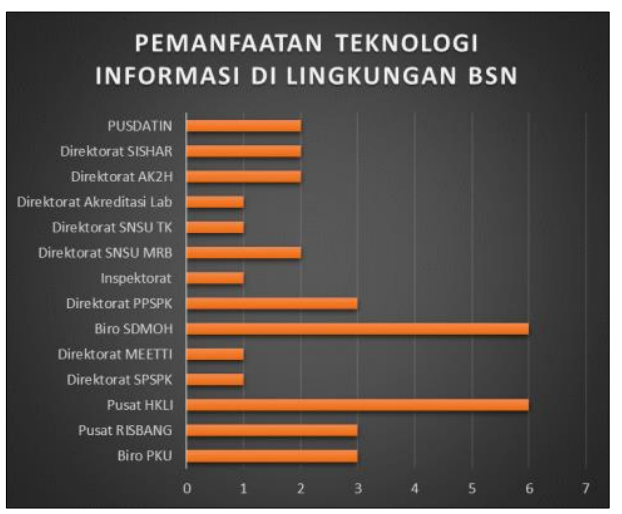

Gambar 4. Pemanfaatan Teknologi Informasi di Lingkungan BSN

Seiring meningkatnya pemanfaatan teknologi informasi di lingkungan BSN, maka semakin beragam pula baik bahasa pemrograman, framework pemrograman maupun database yang digunakan pada aplikasi-aplikasi di lingkungan BSN. Hal ini dikarenakan sebelumnya belum ada kebijakan atau aturan yang mengatur tentang standardisasi spesifikasi sistem informasi di BSN.

Berdasarkan hasil pengolahan data kuesioner kebutuhan teknologi informasi di BSN diperoleh hasil mayoritas bahasa pemrograman yang digunakan menggunakan bahasa pemrograman PHP dengan proporsi nilai $82 \%$, diikuti oleh bahasa pemrograman .NET 3\%, bahasa pemrograman Javascript $12 \%$, dan bahasa pemrograman Java $3 \%$. Hal ini ditunjukkan pada Gambar 4. Selain itu, jenis framework PHP yang paling banyak digunakan yaitu framework Codeigniter dengan hasil $46 \%$, Laravel 15\%, Codekir 12\% dan Non-Framework 27\%. Hal ini ditunjukkan pada Gambar 5.

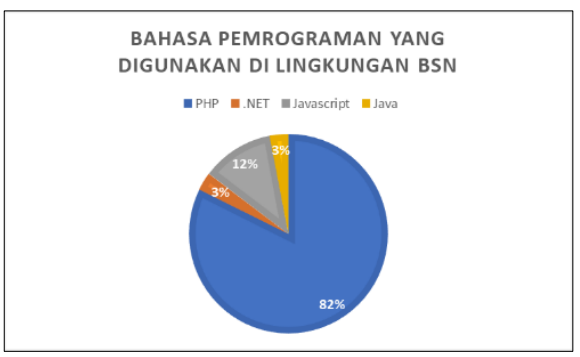

Gambar 5. Bahasa pemrograman yang Digunakan di Lingkungan BSN

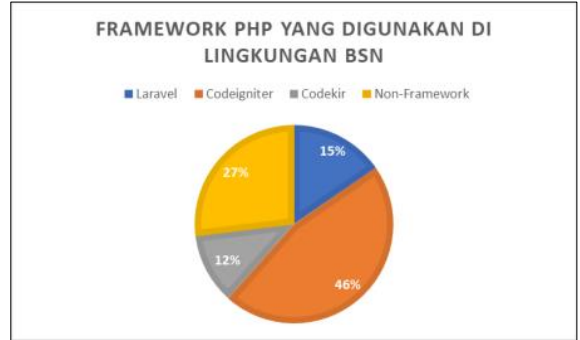

Gambar 6. Framework PHP yang Digunakan di Lingkungan BSN

Selanjutnya, diperoleh hasil bahwa database yang paling banyak digunakan di BSN yaitu MySQL dengan hasil 70\%, diikuti dengan MSSQL Server 2005 15\%, MariaDB 6\%, PosgreSQL 3\%, Oracle 12c 3\% dan MSSQL Server 2017 3\%. Hal ini ditunjukkan pada Gambar 6.

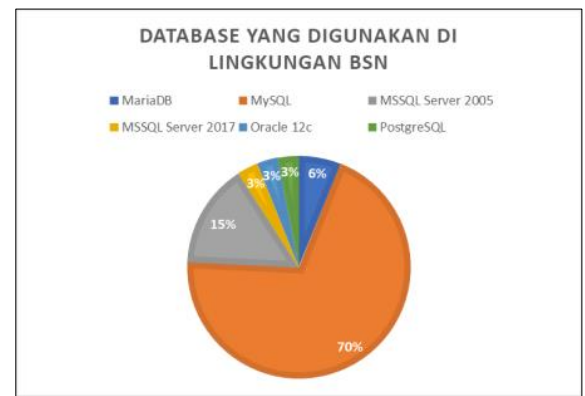

Gambar 7. Database yang Digunakan di Lingkungan BSN

Hasil pengolahan data kuesioner kebutuhan TIK di atas menunjukkan bahwa manajemen di BSN harus menyediakan sumber daya manusia terkait bidang teknologi informasi dan komunikasi (TIK) yang memiliki kemampuan menggunakan Bahasa pemrograman PHP dan memiliki kemampuan menggunakan framework Codeigniter dan Laravel serta kemampuan database MySQL. Hal ini diselaraskan dengan upaya peningkatan kompetensi staf bidang TIK dengan pelatihan bahasa pemrograman PHP dengan framework Codeigniter atau Laravel dan pelatihan database MySQL dan pelatihan lainnya terkait kompetensi di bidang TIK sehingga perlunya koordinasi dengan Biro Perencanaan, Keuangan dan Umum dan Biro Sumber Daya Manusia, Organisasi dan Hukum. Koordinasi yang dilakukan pun harus berpedoman pada peraturan/kebijakan yang ada sedangkan di BSN belum ada peraturan yang hal tersebut. Oleh karena itu, manajemen BSN terkait bidang TIK pun menyusun Kebijakan Internal Anggaran dan Belanja TIK BSN yang 
mengatur penyusunan, perencanaan, serta koordinasi terkait kebutuhan TIK di BSN.

Di samping itu, dengan banyaknya aplikasi yang digunakan di lingkungan BSN, terdapat irisan dan tumpang tindih data sehingga diperlukannya integrasi baik di sistem maupun data yang digunakan. Berdasarkan hasil pengolahan kuesioner kebutuhan teknologi informasi di BSN, terlihat komposisi perbandingan antara aplikasi BSN yang berinteraksi dengan aplikasi lain dengan bobot nilai $40 \%$ dengan aplikasi BSN yang tidak berinteraksi (stand alone) dengan bobot nilai $60 \%$ yang terlihat di Gambar 7 di bawah ini. Hal ini menunjukkan bahwa kebutuhan integrasi untuk proses interoperabilitas di infrastruktur sistem informasi di BSN semakin dibutuhkan mengingat masih ada $60 \%$ aplikasi yang berlum berinteraksi yang masih memiliki celah untuk redudansi data dan overlapping proses bisnis sehingga mendasari disusunnya Kebijakan Internal Integrasi Sistem Aplikasi, Kebijakan Peggunaan Aplikasi Umum Berbagi Pakai dan Kebijakan Internal Inovasi Proses Bisnis Terintegrasi. Ketiga kebijakan ini mengatur tentang upaya-upaya yang dianjurkan untuk dilakukan untuk mendukung proses integrasi sistem informasi dan menggunakan aplikasi umum berbagi pakai Kementerian dan Lembaga Non Kementerian lain guna meminimalkan anggaran instansi dalam pengajuan pembuatan aplikasi baru dengan proses bisnis yang sama serta menyederhanakan proses bisnis di lingkungan BSN.

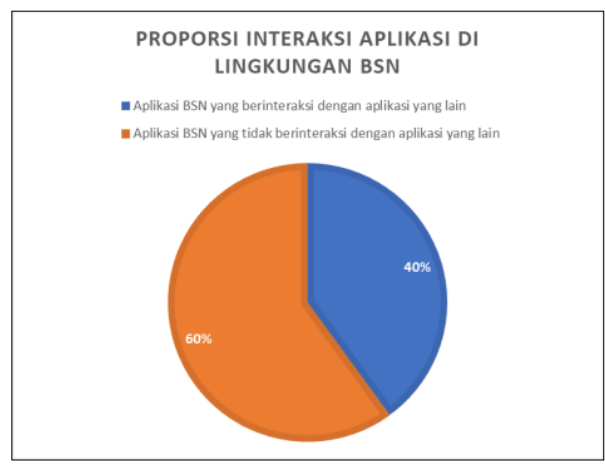

Gambar 8. Proporsi Interaksi Aplikasi di Lingkungan BSN

Untuk mendukung pemanfaatan teknologi informasi yang semakin meningkat di BSN, Pusat Data dan Sistem Informasi yang merupakan salah satu unit kerja eselon II di BSN yang bertugas sebagai pusat layanan data membutuhkan fasilitas infrastruktur, manajemen dan perencanaan pemulihan bencana yang baik dan terstruktur untuk meningkatkan produktivitas dan memberikan layanan yang optimal walaupun terjadi suatu bencana. Hal ini mendasari penyusunan Kebijakan Internal Pengoperasian Data yang merupakan salah satu indikator dalam evaluasi SPBE di BSN.

Survey kebutuhan teknologi informasi yang dilakukan tidak hanya terkait aplikasi-aplikasi yang digunakan di lingkungan BSN, namun juga terkait kebutuhan software maupun hardware untuk masing-masing unit kerja esleon II yang memiliki tingkat urgensi yang berbeda-beda. Pada gambar 8 , terlihat bahwa software yang paling banyak berupa Adobe sebanyak 163 buah, Microsoft 127 buah, diikuti oleh Bruel \& Kjaer 6 buah, Corel Draw 2 buah, Lab View, Matlab maupun PRO Lab plus masing-masing 1 Buah.

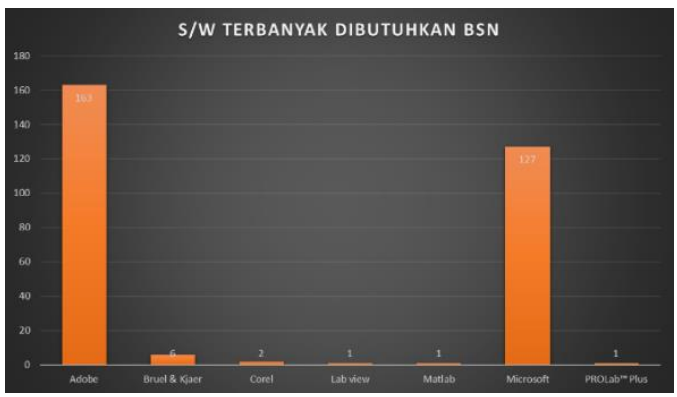

Gambar 9. Software Terbanyak yang Dibutuhkan di Lingkungan BSN

Selanjutnya, tingkat urgensi kebutuhan software di lingkugan BSN berdasarkan gambar 9 yaitu memiliki nilai yang didominasi oleh urgensi "Segera" dengan nilai $61 \%$, "Ssangat Segera" dengan nilai $36 \%$ dan "Biasa" dengan nilai $3 \%$.

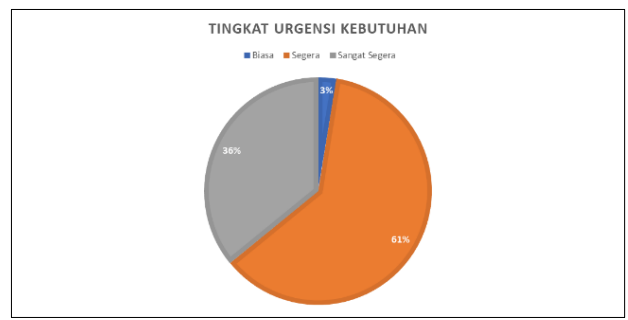

Gambar 10. Tingkat Urgensi Kebutuhan Software di Lingkungan BSN

Selain itu, jumlah software yang dibutuhkan dengan tingkat urgensi "Sangat Segera" dan "Segera" yaitu didominasi oleh Adobe Reader 
Pro dengan jumlah 160 buah, diikuti oleh MS Visio dengan jumlah 85 buah, MS Office 20 buah, Windows 10 Pro dengan jumlah 20 buah, Corel Draw 2 buah, Adobe Premier 2 buah, Adobe After Effect 2 buah, Adobe Photoshop 1 buah, Upgrade Software B\&K 2250 Parameter Waktu Dengung 2 buah, Lab View, Matlab dan Pro Lab Plus masing-masing 1 buah. Hal ini ditunjukkan pada gambar 10 di bawah ini.

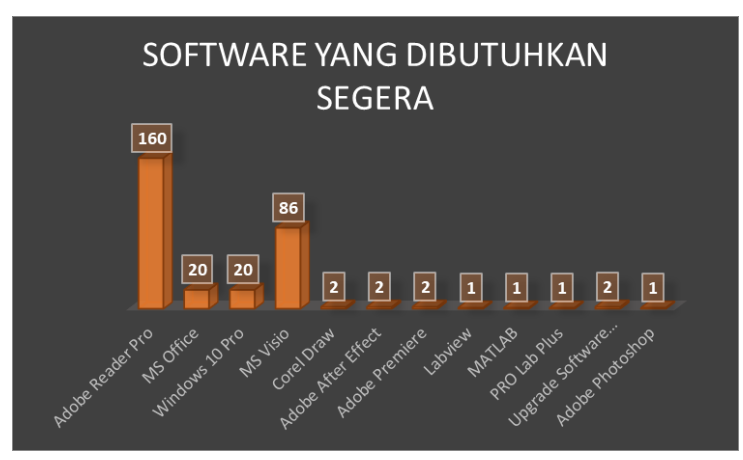

Gambar 11. Software yang Dibutuhkan Segera di Lingkungan BSN

Selain software, terdapat juga hardware yang paling banyak dibutuhkan di dalam pengolah data kuesioner kebutuhan teknologi informasi di lingkungan BSN yang dapat ditunjukkan pada gambar 11 dengan hasil sebagai berikut : PC dengan jumlah 64 buah, Laptop dengan jumlah 35 buah, RAM dengan jumlah 29 buah, Harddisk Eksternal dengan jumlah 22 buah, Printer dengan jumlah 18 buah, Projector dengan jumlah 12 buah, Storage Server 2 buah dan diikuti oleh Converter, Gauge Block Comparator Service, Mesin ULM1000, Perangkat Network, Pointer, Scanner, UPS , maupun Voice Recorder masing-masing 1 buah.

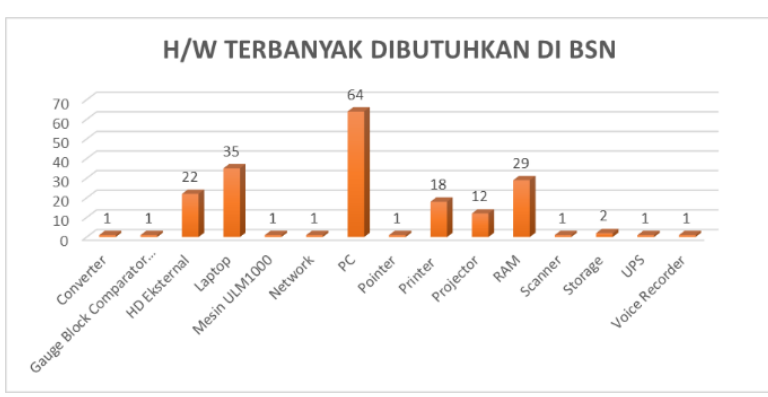

Gambar 12. Hardware Terbanyak yang Dibutuhkan di Lingkungan BSN

Selanjutnya, tingkat urgensi kebutuhan hardware di lingkugan BSN berdasarkan gambar 12 yaitu memiliki nilai yang didominasi oleh urgensi "Sangat Segera" dengan nilai 50\% diikuti oleh tingkat urgensi "Segera" dengan nilai 43\% dan tingkat urgensi "Biasa" dengan nilai $7 \%$.

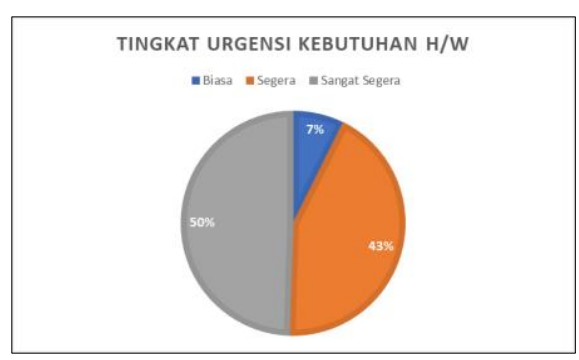

Gambar 13. Tingkat Urgensi Kebutuhan Hardware di Lingkungan BSN

Sedangkan untuk jumlah hardware yang dibutuhkan dengan tingkat urgensi "Sangat Segera" dan "Segera" yaitu didominasi oleh PC dengan jumlah 64 buah, Laptop dengan jumlah 32 buah, RAM dengan jumlah 29 buah, Harddisk Eksternal dengan jumlah 13 buah, Printer dengan jumlah 18 buah, Projector dengan jumlah 10 buah, dan diikuti oleh Storage Server, Converter, Gauge Block Comparator Service, Mesin ULM1000, Perangkat Network, Pointer, Scanner, UPS , maupun Voice Recorder masingmasing 1 buah. Hal ini ditunjukkan pada gambar 13 di bawah ini.

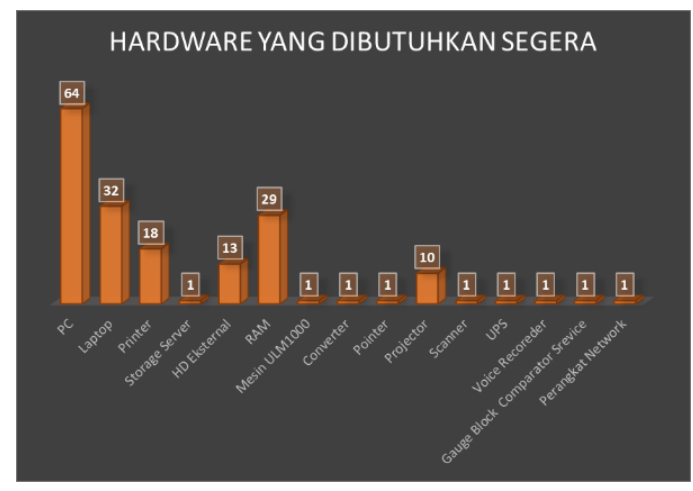

Gambar 14. Hardware yang Dibutuhkan Segera di Lingkungan BSN

Hasil pengolahan data kuesioner terkait kebutuhan teknologi informasi berupa software dan hardware di lingkungan BSN ini merupakan dasar penyusunan Kebijakan Internal Anggaran dan Belanja TIK BSN dimana tingkat urgensi menentukan skala prioritas pengajuan anggaran kebutuhan TIK.

Pada tahapan ini, telah terbentuk 7 indikator kebijakan internal di dalam domain 1 yaitu Kebijakan Internal SPBE pada Aspek 1 yaitu Kebijakan Internal Tata Kelola SPBE. Selanjutnya, penyusunan Aspek 2 terkait 
Kebijakan Internal Layanan SPBE berdasarkan 10 indikator penilaian SPBE yang telah ditentukan oleh Peraturan Menteri Pendayagunaan Aparatur Negara dan Reformasi Birokrasi Republik Indonesia Nomor 5 Tahun 2018 Tentang Pedoman Evaluasi Sistem Pemerintahan Berbasis Elektronik dimana kebijakannya terdiri dari Kebijakan Internal Layanan Naskah Dinas, Kebijakan Internal Layanan Manajemen Kepegawaian, Kebijakan Internal Layanan Manajemen Perencanaan dan Penganggaran, Kebijakan Internal Layanan Manajemen Keuangan, Kebijakan Internal Layanan Manajemen Kinerja, Kebijakan Internal Layanan Pengadaan, Kebijakan Internal Layanan Pengaduan Publik, Kebijakan Internal Layanan Dokumentasi dan Informasi Hukum, Kebijakan Internal Layanan Whistle Blowing System, dan Kebijakan Internal Layanan Publik Instansi Pemerintah.

Hasil pengolahan data kuesioner kebutuhan teknologi informasi di BSN merupakan dasar penyusunan Kebijakan Internal Layanan SPBE BSN yang telah ditetapkan menjadi Keputusan Kepala Badan Standardisasi Nasional Nomor 316A/KEP/BSN/7/2019 tentang Pernyataan Kebijakan Internal Layanan Sistem Pemerintahan Berbasis Elektronik.

Hasil nilai indeks domain kebijakan pada evaluasi penerapan SPBE di BSN pada tahun 2018 sebesar 1.88 yang dapat dilihat pada Gambar 15 dibawah ini.

\begin{tabular}{|c|c|}
\hline Domain Kebijakan SPBE & 1,88 \\
\hline Kebijakan Tata Kelola SPBE & 1,29 \\
\hline Kebijakan Layanan SPBE & 2,30 \\
\hline
\end{tabular}

Gambar 15. Hasil Nilai Indeks Domain Kebijakan SPBE BSN 2018

Setelah dilakukannya implementasi kebijakan internal SPBE BSN, diperoleh peningkatan nilai indeks domain kebijakan sebesar 4.12 dimana sebelumnya pada tahun 2018 diperoleh nilai 1.88. Nilai tersebut diperoleh berdasarkan hasil penilaian mandiri (selfassessment) terhadap tingkat kematangan pnerapan SPBE. Hal ini ditunjukkan pada Gambar 16 dibawah ini.

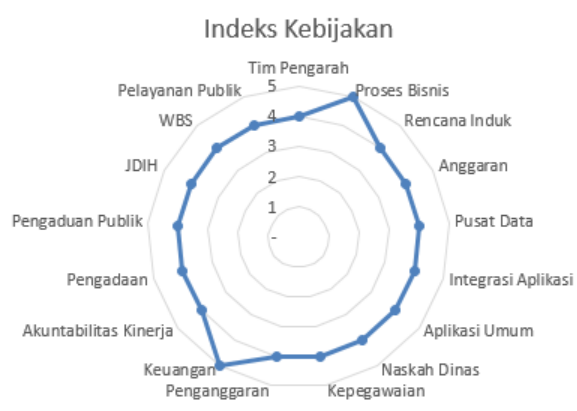

Gambar 16. Grafik Hasil Nilai Indeks Domain Kebijakan yang Diharapkan

\section{KESIMPULAN}

Hasil pengolahan data kuesioner terhadap kebutuhan TIK di lingkungan BSN tahun 2019 memberikan perspektif yang bernilai objektif terhadap penyusunan Kebijakan Internal SPBE pada domain 1 dengan Aspek 1 terkai Kebijakan Internal Tata Kelola SPBE dan Aspek 2 terkait Kebijakan Internal Layanan SPBE dengan 17 indikator kebijakan di lingkungan BSN.

Selain itu, hasil pengolahan data kuesioner juga memberikan proyeksi pemetaan kompetensi sumber daya manusia khususnya di bidang teknologi informasi dan komunikasi di lingkungan BSN.

Penerapan kebijakan internal SPBE di lingkungan BSN melalui penetapan Keputusan Kepala BSN dinilai cukup efektif dalam meningkatkan nilai indeks domain kebijakan SPBE di BSN. Hal ini diketahui berdasarkan adanya peningkatan nilai indeks yang sebelumnya sebesar 1.88 di tahun 2018 menjadi 4.06 di tahun 2019 pada penilaian mandiri SPBE 2019.

Namun, hasil pengolahan data kuesioner terhadap kebutuhan TIK di lingkungan BSN tahun 2019 yang sudah dilakukan belum dapat digunakan sebagai pendukung area perubahan pada domain 2 terkait Tata Kelola SPBE dan domain 3 terkait Layanan SPBE pada penilaian evaluasi SPBE karena dibutuhkan survei lanjutan dengan skala yang lebih luas. Selanjutnya, diharapkan terdapat perbaikan berupa monitoring dan evaluasi berkelanjutan terhadap Tata Kelola Kelembagaan, Strategi dan Perencaaan, TIK , Layanan Administrasi Pemerintahan Berbasis Elektronik dan Layanan Publik Berbasis Elektronik di lingkungan BSN agar domain 2 dan domain 3 terpenuhi sehingga penerapan SPBE di BSN bisa berjalan maksimal dan tujuan SPBE pun bisa dicapai. 


\section{UCAPAN TERIMA KASIH}

Dalam penyusunan penelitian ini tidak terlepas dukungan dari berbagai pihak. Penulis secara khusus mengucapkan terima kasih yang sebesar-besarnya kepada semua pihak yang telah membantu. Penulis banyak menerima bimbingan, petunjuk dan bantuan serta dorongan dari berbagai pihak baik yang bersifat moral maupun material. Pada kesempatan ini penulis menyampaikan rasa terima kasih yang sebesar-besarnya kepada:

1. Tuhan Yang Maha Esa dengan segala rahmat serta karunia-Nya yang memberikan kekuatan bagi peneliti dalam menyelesaikan penelitian ini.

2. Kepada keluarga tercinta yang selama ini telah membantu penulis dalam bentuk perhatian, kasih sayang, semangat, serta doa yang tidak hentihentinya mengalir demi kelancaran dan kesuksesan peneliti dalam menyelesaikan penelitian ini.

3. Kepada Bapak Drs. Slamet Aji Pamungkas, M.Eng, selaku Kepala Pusat Data dan Sistem Informasi BSN yang selalu memberikan bimbingan, arahan, dorongan, dan semangat kepada peneliti, sehingga penelitian ini dapat terselesaikan.

4. Kepada Bapak Budi Triswanto, ST, selaku Kepala Bidang Sistem Informasi dan Tata Kelola Data BSN yang selalu memberikan dukungan, perhatian, semangat dari awal hingga terselesaikannya penelitian ini.

5. Kepada Bapak Akbar Aryanto, ST, selaku Kepala Bidang Infrastruktur dan Keamanan Informasi BSN yang senantiasa memberikan dukungan, arahan, bimbingan.

6. Segenap Pegawai dan staff Badan Standardisasi Nasional yang selalu membantu dalam memberikan fasilitas, ilmu, serta pendidikan pada penulis hingga dapat menunjang dalam penyelesaian penelitian ini

\section{DAFTAR PUSTAKA}

Gunawan, Imam.(2013). Metode Penelitian Kualitatif:Teori dan Praktik.Jakarta: Bumi Aksara.

ISACA.(2010). IT Standards, Guidelines, Tools and Techniques for Audit and Assurance and Control Professionals. Illinois: ISACA.
ISO.(2016).ISO/IEC $38500 \quad$ Information Technology -- Governance Of It For The Organization.Jenewa: ISO.

Indrajit,RE.(2016). Konsep Dasar Tata Kelola Teknologi Informasi.Jakarta: the preinexus Indonesia.

Pemerintah Indonesia.(2018).Peraturan Presiden Nomor 95 Tahun 2018 Tentang Sistem Pemerintahan Berbasis Elektronik.Jakarta: Sekretariat Negara.

Pemerintah Indonesia. (2007).Permenkominfo No.41 Tahun 2007 Tentang Panduan Umum Tata Kelola Teknologi Informasi dan Komunikasi Nasional.Jakarta: Kementrian Komunikasi dan Informatika.

Pemerintah Indonesia.(2019).Keputusan Kepala Badan Standardisasi Nasional Nomor 316A/KEP/BSN/7/2019 tentang Pernyataan Kebijakan Internal Layanan Sistem Pemerintah Berbasis Elektronik.Jakarta: Badan Standardisasi Nasional.

Pemerintah Indonesia.(2018).Peraturan Menteri Pendayagunaan Aparatur Negara dan Reformasi Birokrasi Republik Indonesia Nomor 5 Tahun 2018 Tentang Pedoman Evaluasi Sistem Pemerintahan Berbasis Elektronik.Jakarta: Menteri Pendayagunaan Aparatur Negara dan Reformasi Birokrasi.

Ramdani,Dani.(2018).Peta dan Tata Kelola TIK Institusi Pemerintah. Sleman: Diandra Kreatif.

Saxena, N.C.(2012).Administrative Reforms For Better Governance.New Delhi: National Sosial Watch. 